\title{
DIABETINÉS KETOACIDOZĖS GYDYMO IR BAIGTIES ASPEKTAI
}

\author{
Dalia Adukauskienè $\dot{1}^{1}$, Laura Jokūbonienè ${ }^{1}$, Edita Kazėnaite் ${ }^{2}$, \\ Edita Mašanauskiené ${ }^{3}$, Auksė Gečioniene $\dot{3}^{3}$ \\ ${ }^{1}$ Lietuvos sveikatos mokslu universiteto Medicinos akademija, \\ ${ }^{2}$ Vilniaus universiteto Medicinos fakultetas, \\ ${ }^{3}$ Lietuvos sveikatos mokslu universiteto Kauno ligonine
}

Raktažodžiai: diabetinè ketoacidozè, cukrinis diabetas, hipokalemija, hipoglikemija, natrio bikarbonatas.

\begin{abstract}
Santrauka
Tyrimo tikslas - ištirti dažnos endokrininès patologijos - diabetinès ketoacidozès (DKA) kaip cukrinio diabeto (CD) dekompensacijos gydymo komplikacijas, jų etiologiją bei sąsają su gydymo intensyviosios terapijos skyriuje (ITS) trukme, ir, remiantis tyrimo duomenimis, suteikti konkrečias galimybes klinicistams optimizuoti gydymo taktiką ir su tuo susijusias gydymo baigtis.

Metodika. Atlikta retrospektyvinè kohortinè studija. Imtis - 120 pacientu, gydytų dèl DKA tretinio lygio universitetinès ligoninès ITS 6 metu periodu. Bioetikos centro leidimas (Nr. BEC - MF - 492). Tirtos DKA gydymo komplikacijos bei natrio bikarbonato naudojimas ir jų sąsaja su gydymo trukme ITS. Statistiniams skaičiavimams naudota SPSS 23.0 paketo versija. Požymiai vertinti kaip statistiškai reikšmingi, kai $p<0,05$.

Rezultatai.Nustatytos dažniausios DKA priežastys: piktnaudžiavimas alkoholiu (29\%), üminė infekcija (28 $\%$ ), insulino vartojimo sutrikimai (28\%), sunkios gretutinès ūminès ligos (5\%), neaiškios (10\%). DKA gydymo metu hipokalemija diagnozuota 53 proc. pacientu, gydymo ITS trukmė $52,9 \pm 29,7$ vs $32,8 \pm 18,6$ val., $\mathrm{p}<0,05$. Skiriant gydymą insulinu, hipoglikemija diagnozuota 18 proc. atveju, gydymo ITS trukmè 63,2 $\pm 38,5$ vs $38,9 \pm 21,2$ val., $p<0,05$. Hipoglikemijos ar normoglikemijos atvejais, išliekant ketoacidozei, insulino skyrimas klaidingai nutrauktas 33 proc. pacientų, gydymo ITS trukme $56,5 \pm 30,7$ vs $37,0 \pm 22,5$ val., $\mathrm{p}<$ 0,05 . Simptominiam ketoacidozès gydymui esant stabiliai hemodinamikai natrio bikarbonato tirpalai paskirti 28 proc. pacientu, gydymo ITS trukmé $55,2 \pm 27,5$ vs $39,1 \pm 25,6$ val., $p<0,05$. Bendra DKA gydymo ITS trukmè 9 - $163(45,1 \pm 34,2)$ val.: dèl infekcijos $19-163$
\end{abstract}

$(61,7 \pm 41,0)$, neinfekcinių priežasčių $9-97(31,6 \pm$ 19,4) val., $\mathrm{p}<0,05$.

Išvados. Piktnaudžiavimas alkoholiu, ūminè infekcija bei insulino dozavimo pažeidimas - priežastys, predisponavusios diabetinę ketoacidozę. Hipokalemija, hipoglikemija, ankstyvas insulino nutraukimas, išliekant ketoacidozei, natrio bikarbonato skyrimas nustatyti kaip diabetinès ketoacidozès gydymo komplikacijos, ilginusios gydymo trukmę intensyviosios terapijos skyriuje. Infekcinès komplikacijos dvigubai ilgino gydymo intensyviosios terapijos skyriuje trukmę.

\section{Ivadas}

DKA yra dažna ir gyvybei pavojinga CD komplikacija, kuri gali išsivystyti bet kokiame amžiuje, sergant ịvairių tipų CD. Ši ūminè metabolinẻ CD komplikacija pasireiškia ryškia triada: hiperglikemija, ketonemija ir metaboline acidoze. DKA skatina ne tik insulino trūkumas organizme, kuris sukelia hiperglikemiją, nes blokuoja gliukozès patekimą i ląsteles ir suaktyvina glikogenolizę bei gliukoneogenezę, bet ir ji didinantis insulino antagonistu - streso hormonu (gliukagono, kortizolio, augimo hormono ir katecholaminų) perteklius. Jie dar labiau skatina hiperglikemiją dèl gliukozès prekursoriu pertekliaus, skatindami proteolizę ir lipolizę bei insulino dar paryškejjusio deficito fone gausèjančių laisvujjų riebalų rūgščių virsmą ketoniniais kūnais ir ketonemijos bei metabolinès acidozès išsivystymą [1-7].

Dažniausiai DKA paskatina infekcija, insulino vartojimo sutrikimai, piktnaudžiavimas alkoholiu, sunkios gretutinès ligos ar kiti veiksniai [2,3].

DKA metu vyrauja hiperglikemija, tačiau pradejjus gydymą insulinu, gereja gliukozès ịsisavinimas ląstelèse, slopinama glikolize, proteolizè, lipolizè ir gliukoneogenezè bei ketogenezè, todèl mažèja gliukozès koncentracija serume [1-7]. Tokiu būdu patogenetiniu pagrindu koreguojama pati ketoacidozè, o simptominis acidozès mažinimas natrio bi- 
karbonato tirpalais, ypač esant stabiliai hemodinamikai, nèra indikuotinas dar ir dèl akivaizdžių patogenetinių ketoacidozès ypatumų [5]. Dėl ketoacidozès ženkliai padažnėjęs kvèpavimas atlieka savo paskirti - kompensuoja metabolinę acidozę respiracine alkaloze, apsaugant nuo kliniškai jau reikšmingo $\mathrm{pH}$ pokyčio kraujyje [2-4]. Sunki acidemija skatina hemodinamikos nestabilumą dèl mažejančio miokardo kontraktiliškumo, vazodilatacijos ir todèl nepakankamos reakcijos ị hemodinamikos stabilizavimui skiriamus katecholaminus. Nors stokojama ịrodymų apie gydymo bikarbonatais naudą, daugelis klinicistų vis dar taiko šarminimą intraveniniais bikarbonato tirpalais kaip simptominę $\mathrm{pH}$ mažinimo priemonę [4].

Dèl hiperglikeminès osmosinès diurezès, vėmimo, kalio re-entry į ląsteles, metabolinę acidozę gydant insulinu, DKA metu vystosi hipokalemija $[2,3,6]$. Neatsižvelgiant ị kraujo $\mathrm{pH}$, skaitlinè kalio koncentracija serume gali klaidinti, nes pagal ją gali būti normo- ar hiperkalemija, laikinai priklausanti nuo patogenetinių ir kompensacinių reiškinių - acidozès ir insulino stokos. Vos tik pradejjus DKA gydymą insulinu, gliukozė ir kalis sparčiai grąžinami ị ląsteles, todèl anksti nepaskyrus kalio papildymo, tiek klinikoje, tiek ir laboratoriniuose tyrimuose išryškèja ženkli hipokalemija su jai būdinga įvairialype klinikine išraiška. Išimtis ankstyvam kalio papildymui - terminalinis inkstų funkcijos nepakankamumas. Hipoglikemija, skiriant pernelyg dideles insulino dozes, neintensyvinant gliukozès tirpalų vartojimo, tampa sunkiai išvengiama [1-6]. Tokia hipoglikemijos rizika insulino terapijos metu padidejja, kai glikemija pasiekia $11-14$ $\mathrm{mmol} / \mathrm{l}[3,6]$.

Sergančiojo nuolatine diabetine ketoacidoze būklès, gliukozès, kraujo $\mathrm{pH}$, kalio koncentracijos stebėsena ir racionali interpretacija bei pasirinktas optimalus gydymas adekvačiomis insulino dozėmis, savalaikiu gliukozės tirpalų vartojimu bei natrio bikarbonato simptominio neskyrimo pagrịstumu sudaro prielaidą išvengti gyvybei pavojingų gydymo komplikacijų, pagreitinti gijimą ir trumpinti gydymo ITS trukmę $[2,3,6]$. Aktualu efektyviau gydyti pacientą atsižvelgiant i patogenetinį ligos mechanizmą, o ne tik siekti laboratorinių pokyčiu simptominio koregavimo skaitlinių įverčių. Tuo sudaromos galimybès mažinti gydymo ITS trukmę, o kartu ir gydymo išlaidas, susijusius su ypač brangiais ITS lovadieniais bei išvengti hospitalinių infekcijų, kurių sąsaja su gydymo trukme ITS seniai žinoma.

Tyrimo tikslas - ištirti dažnos endokrininès patologijos - DKA, kaip CD dekompensacijos, gydymo komplikacijas, jų etiologiją bei sąsają su gydymo ITS trukme, ir, remiantis tyrimo duomenimis, suteikti konkrečias galimybes klinicistams optimizuoti gydymo taktiką ir su ja susijusias baigtis.

\section{Tyrimo medžiaga ir metodai}

Atlikta retrospektyvinè kohortinè studija tretinio paslaugų lygio universitetinès ligoninès Intensyviosios terapijos skyriuje (ITS) 6 metu periodu. Bioetikos centro leidimas (Nr. BEC - MF - 492). Iš viso analizuotos 136 pacientų, gydytų ITS dèl diagnozuotos DKA, ligos istorijos. Itraukimo ị tyrimą kriterijai: amžius $\geq 18$ m., CD (žinomi 1,2 tipo ir naujai diagnozuoto $\mathrm{CD}$ atvejai), hospitalizavimas ITS dèl išsivysčiusios CD komplikacijos - DKA, kai pH < 7,3; $\mathrm{HCO}_{3}{ }^{-}<18 \mathrm{mmol} / \mathrm{l}$, gliukozès koncentracija kraujo serume $>11,1 \mathrm{mmol} / 1$, teigiamas ketonų šlapime testas. Neittraukimo kriterijai: nėra acidozès kraujo dujų tyrime, neatliktas šlapimo tyrimas, šlapimo tyrime nèra ketonurijos.

Analizuota: DKA priežastys, gliukozès, kalio koncentracija kraujo serume, kraujo $\mathrm{pH}$ su $\mathrm{HCO}_{3}^{-}$verte, ketonurija, DKA priežastys, DKA gydymo metu išsivysčiusios komplikacijos (hipokalemijos epizodai, kai kalio kraujo serume $<3,5 \mathrm{mmol} / \mathrm{l}$, hipoglikemijos, kai gliukozès koncentracija kraujo serume $<3,3 \mathrm{mmol} / \mathrm{l}$ ). Hipokalemija skirstyta į 2 grupes: pirminè, kai diagnozuota dar nepradejjus taikyti DKA gydymo, ir antrinè, išsivysčiusi jau DKA gydymo metu. Tirta hipokalemijos, hipoglikemijos, natrio bikarbonato skyrimo ir insulino nutraukimo, išliekant ketonurijai, sąsaja su gydymo ITS trukme.

Statistiniams skaičiavimams naudota SPSS 23.0 paketo versija. Statistinei duomenų analizei taikytas $\chi^{2}$ požymių priklausomybès testas. Student's t kriterijus vidurkių statistiniams skirtumams nustatyti bei procentiniai dažniai. Atliktas duomenų skaitinių charakteristikų skaičiavimas. Požymiai vertinti kaip statistiškai reikšmingi, kai $\mathrm{p}<0,05$.

\section{Tyrimo rezultatai}

Tyrimo apimtis - 120 DKA sergančių pacientų, iš jų $67(56 \%)$ moterys $(\mathrm{p}>0,05)$. Pacientų amžius 18-92 (44,9 $\pm 19,3)$ metai. Diagnozuotas 1 tipo CD 81(68 \%) atvejų (p < $0,05)$. CD (1 tipo) pirmą kartą diagnozuotas jau išsivysčius DKA $13(11 \%)$ pacientų.

Nustatytos DKA priežastys: lètinis piktnaudžiavimas alkoholiu 35(29\%), ūminè infekcija 34 (28 \%) atvejų (dažniau pneumonija 16/34 (47\%), šlapimo takų infekcija bei sepsis), insulino vartojimo sutrikimai $33(28 \%)$, sunkios gretutinès ūminès ligos 6(5\%), neaiškios priežastys $12(10 \%)$ atvejų.

Hipokalemija DKA atveju ITS diagnozuota 64(53\%) pacientams, kai kalio koncentracija serume 2,1-3,4 (3,1 \pm $0,3) \mathrm{mmol} / \mathrm{l}$. Nepradejjus DKA gydymo, 38 (32\%) pacientai atvyko su išsivysčiusia pirmine hipokalemija, o kitiems $82(68 \%)$ pacientams kalemija vertinta kaip normo- ar hiperkalemija. Neatsižvelgus ị pH reikšmę (pH 6,8 - 7,3 $(7,0 \pm 0,1)), 49 / 82(60 \%)$, pacientams kalemija $(3,5-7,1$ $(5,1 \pm 0,9) \mathrm{mmol} / \mathrm{l})$ pagal skaitinę reikšmę buvo klaidingai 
interpretuota kaip pseudo normo- ar hiperkalemija, todèl netaikant korekcijos kalio papildymu, 26 (22\%) išsivystė antrine hipokalemija (1 pav.).

Skiriant insulino terapiją, hipoglikemija diagnozuota 22 $(18 \%)$ atvejais, gliukozès koncentracija kraujo serume 1,2 $-3,3(2,5 \pm 0,7) \mathrm{mmol} / \mathrm{l}$. Esant hipoglikemijai ar normoglikemijai, 39(33\%) atvejais insulino skyrimas tebesitęsiančios ketoacidozès kontrolei nutrauktas klaidingai, nes hipoglikemijos kontrolę užtikrino gliukozès intraveninių tirpalų skyrimas, o ketonurijos, kaip ketoacidozès, koreguojamos tik insulinu, išraiška išliko.

Simptominiam ketoacidozès gydymui pirmają gydymo parą 4,2 proc. natrio bikarbonato i/v tirpalai skirti $33(28 \%)$ atvejais, kai pH 6,8 - 7,2 (6,9 $\pm 0,1), \mathrm{HCO}_{3}^{-} 1,1-11,5(4,8 \pm$ $3,3) \mathrm{mmol} / \mathrm{l}$. Dèl to bikarbonatinis buferis padidejo nuo 4,8 $\pm 3,3$ iki 7,9 $\pm 3,1,(\mathrm{p}<0,05)$, kraujo serumo $\mathrm{pH}$ padidèjo nuo $6,9 \pm 0,1$ iki $7,1 \pm 0,1,(\mathrm{p}<0,05)$, tačiau ketoacidozè išliko visais atvejais $(100 \%)$.

Bendra DKA gydymo ITS trukmè $9-163(45,1 \pm 34,2)$ val.: dèl infekcijos $19-163(61,7 \pm 41,0)$, neinfekciniu priežasčiu $9-97(31,6 \pm 19,4)$ val. $(\mathrm{p}<0,05)$. DKA gydymo ITS trukmès sąsaja su metabolinèms gydymo komplikacijoms: hipokalemija vs normo- ir hiperkalemija atitinkamai $52,9 \pm 29,7$ vs $32,8 \pm 18,6$ val. ( $<<0,05$ ), hipoglikemija vs normo- ir hiperglikemija atitinkamai $63,2 \pm 38,5$ vs $38,9 \pm$ 21,2 val. $(\mathrm{p}<0,05)$. Gydymo ITS trukmės sąsaja su insulino nutraukimu dèl normo- ar hipoglikemijos (išliekant acidozei ir ketonurijai), lyginant su pacientais, kuriems insulinas nebuvo nutrauktas (išliekant acidozei ir ketonurijai): 56,5 $\pm 30,7$ vs $37,0 \pm 22,5$ val. $(\mathrm{p}<0,05)$. Gydymo ITS trukmès sąsaja su i/v natrio bikarbonato tirpalų vartojimu simptominei acidozès korekcijai DKA atveju, lyginant su jų nevartojimu $55,2 \pm 27,5$ vs $39,1 \pm 25,6$ val. $(\mathrm{p}<0,05)$.

\section{Diskusija}

DKA gydymo taktikos pasirinkimas, nors gali atrodyti nesudètinga klinicisto užduotis, yra diskusinis, nes neatsižvelgus ị esminius patogenetinius ir klinikinius aspektus, galimos nepageidaujamos pasekmès. Hipokalemija ir hipoglikemija ịvairiose kritinèse būklèse potencialiai siejamos su mirštamumu ir gali ilginti gydymo trukmę. Šių DKA gydymo komplikacijų dažna priežastis - pasirinktas neracionalus gydymo būdas, todèl šiame straipsnyje aptartos dažniausios DKA komplikacijos: hipokalemija ir hipoglikemija, stebetos įvairiuose kituose tyrimuose, jų pasekmès ir palyginimas su mūsų duomenimis. Be to, nustatème ir kitas gydymo komplikacijas bei jų sąsają su ilgesne gydymo ITS trukme.

DKA dažniausiai išsivysto sergant 1 tipo $\mathrm{CD}$, tačiau daugejja atvejų, kai ji manifestuoja ir kaip 2 tipo CD dekompensacijos išraiška. Mūsų tyrimo duomenys patvirtina kitų autorių paskelbtuosius, kad DKA dažniausiai nustatoma sergantiems 1 tipo CD [8-10]. Tik Tailande atliktame DKA kaip CD dekompensacijos tyrime, pacientai dažniau sirgo 2 nei 1 tipo CD [11].

Daugelio autorių atliktų tyrimų duomenimis, nustatytos dažniausios DKA priežastys - CD gydymo režimo pažeidimas (antidiabetinių medikamentų vartojimo nutraukimas), infekcija, sunkios ūminès ligos, piktnaudžiavimas alkoholiu [7,10-14]. M. Kakusa ir kt. (2016) tyrimo duomenimis, dažniausios DKA išsivystymo priežastys buvo antidiabetinių medikamentų vartojimo režimo pažeidimas 42,5 proc. ir infekcija 22,5 proc., dažniausiai šlapimo ir kvejpavimo takų. Šie rezultatai atitinka mūsų tyrimo rezultatus, išskyrus mūsų tyrime nustatytą vyraujantị piktnaudžiavimą alkoholiu [7]. F. Qari (2015) nustate, kad insulino vartojimo režimo pažeidimas (dozių vartojimo praleidimas) 86,6 proc. bei ūminè infekcija (sepsis) 38,3 proc. - dažniausi DKA predisponavę veiksniai [12]. B. Galm ir kt. (2019) tyrimo duomenimis, sergant cukralige 35 proc. atvejų DKA išsivyste dẻl CD gydymo režimo pažeidimų (visiškas antidiabetinių medikamentų nevartojimas), 33 proc. - infekcija, 19 proc. alkoholio ar narkotikų vartojimas [10]. E. Azoulay ir kt. (2001) paskelbè, kad viena dažniausių DKA išsivystymo priežasčių yra ūminè infekcija (41,5\%) ir insulino vartojimo sutrikimai $(24,3 \%)$, retesnès priežastys - ūminis miokardo infarktas (5,7\%), piktnaudžiavimas alkoholiu (1,6\%) [13]. L. Randall ir kt. (2011) tyrimo duomenimis, 39 proc. visų DKA atvejų yra siejama su narkotikų, 33 proc. su alkoholio vartojimu, 16 proc. su reguliariu gydymo režimo pažeidimu, kai tiriamieji priklausė socialinės rizikos grupei (benamiai, dažni ịkalinimo įstaigų klientai) [14]. Mūsų tyrime dažniausiai (29 \% atvejų) DKA sukèlè piktnaudžiavimas alkoholiu. Tai buvo dažniau pasitaikantis veiksnys, nei daugelyje kitų publikacijų, kuriose dažnesnè priežastis buvo insulino vartojimo sutrikimai ar infekcija. Atvirkščiai, ūminè infekcija



1 pav. Pirminè ir antrinè hipokalemija diabetinès ketoacidozès atveju 
mūsų tyrime, priešingai nei kitų tyrèjų, kaip DKA priežastis nustatyta rečiau, nors ir išlieka tarp vyraujančiu predisponuojančių veiksnių. Daugelis tyrejų nustatė didesnį insulino vartojimo pažeidimų dažnį, nei mūsų tyrime.

W. Crasto ir kt. (2015) tyrime, remiantis DKA gydymo vidinio audito analize ir Jungtinès Karalystès diabeto draugijos DKA gydymo gairemis, nustatyta, kad DKA gydymo metu dažniausios jatrogeninės komplikacijos - hipokalemija išsivystė 46 proc., o hipoglikemija 40 proc. pacientu [15]. Analogiškai ir K. Dhatariya ir kt. (2015) Jungtinejje Karalysteje atliktame DKA gydymo ypatumų tyrime, kuriame dalyvavo 72 ligoninès: hipokalemija išsivyste daugiau nei pusei, o hipoglikemija - trečdaliui sergančiujų DKA [16]. Y. Thewjitcharoen ir kt. (2019) atliktame 14 metų laikotarpio tyrime Tailande nustatyta, kad gydant sergančiuosius DKA, hipokalemijos (27 \%) išsivystymo dažnis yra dvigubai didesnis, nei hipoglikemijos (13\%), kurios dažnis net 3 kartus mažesnis, negu nustatytas kitose britų studijose [11]. Vis dèlto hipoglikemija dar rečiau nei kituose tyrimuose nustatyta B. Galm ir kt. (2019) trijų Kanados ligoninių tyrime: hipokalemija (42\%) buvo dažnesnè gydymo komplikacija, nei hipoglikemija (6\%) [10]. Labai panašius ị mūsų radinius nustate F. Pasquel ir kt. (2019), dviejose JAV universitetinėse ligoninėse analizavę sergančiujų DKA gydymo sukeltas komplikacijas: hipokalemija - 54 proc., hipoglikemija - 16 proc. DKA atvejų [17].

Mūsų atliktame tyrime, kaip ir daugelyje kitų publikacijų, hipokalemija kaip DKA gydymo komplikacija diagnozuota daugiau nei pusei pacientų. Visos minètos studijos parodo, kad hipokalemija yra pati dažniausia DKA gydymo komplikacija, todèl norint reikšmingai mažinti jos išsivystymą, svarbu kuo anksčiau identifikuoti jos atsiradimą skatinančias priežastis. $1990 \mathrm{~m}$. mokslinèje literatūroje paskelbti duomenys, kad sumažejjus kraujo $\mathrm{pH}$ reikšmei 0,1 , kalemija didèja apie $0,4 \mathrm{mmol} / \mathrm{l}$, todèl kalio koncentracijos interpretavimas atsižvelgiant ị kraujo pH reikšmę yra būtinas, siekiant teisingai ir anksti diagnozuoti sutrikimą, nedelsiant pradèti kalio papildymą, tuo efektyviai mažinant hipokalemijos išsivystymo dažnị [18]. Mūsų tyrime nagrinèdami hipokalemijos išsivystymo priežastis nustatėme, kad kalio papildymas neskirtas ar pavèluotas neatsižvelgus i kraujo $\mathrm{pH}$ vertę, dèl to kalio koncentracija ịvertinta klaidingai. Neatsižvelgus i i pH reikšmę, daugiau kaip pusei pacientų hipokalemija klaidingai interpretuota kaip normo- ar hiperkalemija, korekcija ankstyvu kalio papildymu netaikyta, todèl beveik pusei iš jų išsivystė hipokalemija. Kadangi publikuotų klinikinių tyrimų, o kartu ir duomenų apie kalio koncentracijos priklausomybę nuo $\mathrm{pH}$ vertès DKA gydymo metu stokojama, todèl skatiname klinicistus ir mokslininkus vykdyti stebèseną šiuo aspektu, optimizuojant DKA pacientų gydymą.
Mūsų tyrimo duomenimis, hipoglikemija išsivystè penktadaliui DKA atvejų, ir tai yra retesne pavojinga komplikacija, nei skelbta kitose publikacijose $[15,16]$. Tai patvirtintų tinkamą glikemijos stebèseną bei kontrolę tiriamajame padalinyje. Vis dèlto trečdaliui pacientų hipoglikemijos klaidingai bandyta išvengti visai nutraukiant insuliną, nustačius hipoar normoglikemiją, išliekant ketoacidozei ir ketonurijai, tik intensyvinant gliukozès tirpalų skyrimą dèl normoglikemijos. Tokiu atveju, kai ryškus insulino deficitas sukelia DKA, o jo skyrimas nutraukiamas, ketoacidozè užsitęsia, ilgèja gydymo trukmė ITS, didèjant hospitalinès infekcijos rizikai, kuriai tiriamieji ypač jautrūs dèl imunosupresijos. Tikslinga dar labiau optimizuoti DKA gydymą, vengiant patofiziologiškai nepagrịsto, todèl klaidingo insulino nutraukimo dèl hipoglikemijos, jei esti ketonurija; pakaktų mažinti insulino dozę ir intensyvinti gliukozès tirpalų infuziją. Insulino nutraukimo taktika, esant DKA, parodé blogesnę gydymo baigti - padidejjusią gydymo ITS trukmę. Deja, publikuotų duomenų apie insulino vartojimo sustabdymą DKA metu išliekant ketonurijai ir itaką gydymo trukmei nepakanka. Mūsų tyrimo duomenimis, sprendžiant apie insulino tęsimo būtinumą hipo- ir normoglikemijos atveju išliekant ketonurijai, būtina nedelsiant skirti adekvačius kiekius intraveninių gliukozès tirpalų, ir, jei reikia, hipoglikemijos prevencijai mažinti, bet ne nutraukti insulino dozę, kad nepailgètu ketonurijos gydymo ITS trukmè ir būtų pasiekta optimali DKA gydymo baigtis.

Mūsų duomenimis, hipokalemija ir hipoglikemija, išsivysčiusios DKA metu kaip gyvybei grèsmingos komplikacijos, ilgino gydymo ITS trukmę. Analogiškos išvados pateiktos ir J. Krinsley (2011) bei K. Nirantharakumar (2012) studijose. Tyrèjai nustate, kad tiek sergant CD, tiek ir kitam pacientų kontingentui išsivysčiusi hipoglikemija ne tik statistiškai reikšmingai ilgino gydymo ITS trukmę, bet buvo susijusi su padidejjusio mirštamumo rizika ITS [19-21].

Siekiame atkreipti praktikos gydytojų dèmesi gydant DKA i simptominį natrio bikarbonato vartojimą ir jo pasekmes. DKA gydymo metu natrio bikarbonato tirpalų vartojimas pasaulyje vertinamas kontroversiškai, irodymų apie šio tirpalo naudą DKA gydymui, neatsižvelgiant ị specifinę patogenezę, stokojama, tad jie vis dar vartojami klinikinèje praktikoje [5]. Jau ir anksčiau tyrejjai domejjosi šio gydymo itaka. A. Viallon ir kt. (1999) atliktoje retrospektyvinèje studijoje nustate, kad sergantiems DKA pacientams natrio bikarbonato skyrimas neišsprendžia acidozės bei ketonemijos statistiškai reikšmingai greičiau [22]. Vèlesnio K. Latif ir kt. (2002) tyrimo duomenimis, natrio bikarbonato tirpalu vartojimas įtakos greitesniam DKA išgydymui neturèjo [23]. O. Guneysel ir kt. (2008) pristate klinikini atveji apie natrio bikarbonato tirpalo skyrimo neefektyvumą DKA gydymo 
metu [24]. B. Duhon ir kt. (2013) atliktoje retrospektyvinejje studijoje ištyre 86 DKA atvejus, kai $\mathrm{pH}<7,0$, iš kurių pusei skirti $\mathrm{i} / \mathrm{v}$ natrio bikarbonato tirpalai, ir įrodė jų neefektyvumą bei nustate šių pacientų ilgesnę gydymo ITS trukmę su ribiniu statistiniu patikimumu [25]. Mūsų tyrimo duomenimis, analizuojant jau didesnes nei minètame tyrime tiriamujų imtis, patvirtinome radinius jau su statistiniu patikimumu: natrio bikarbonato tirpalas, nepaisant bikarbonatų buferio papildymo, ne tik nekoregavo gydymo objekto - ketoacidozès ir ketonurijos, bet ir statistiškai didino pacientų gydymo ITS trukmę. Natrio bikarbonato tirpalai akivaizdžiai būtų neveiksnūs tiek patogenezès, tiek ir klinikinio atsako atžvilgiu. Jie visais atvejais buvo skirti esant stabiliai hemodinamikai, nors pagrindiné indikacija galètų būti hemodinamikos nestabilumas, jei acidozè sukeltų vazopresoriams atsparią vazodilataciją. S.Green ir kt. (1998) DKA vaikų populiacijoje tyrimo metu nustatyta, kad simptominiam gydymui skyrus natrio bikarbonatą, statistiškai reikšmingai didejo gydymo ITS trukmè [26].

Visos šios studijos įtikinamai parodo, kad simptominis natrio bikarbonato tirpalų skyrimas kaip DKA gydymo metodas - neefektyvus, nors simptomiškai galètų mažinti acidozę $(\mathrm{pH})$ ir didinti buferinị rezervą, esant DKA būdingai patogenezei yra ne tik neracionalus, nepagristas ir todèl neefektyvus, bet gali provokuoti gyvybei pavojingas būkles - su paskatinta hipokalemija siejamus ūminius širdies ritmo sutrikimus, likvoro paradoksinę acidozę ir smegenų edemą, didinti gydymo ITS trukmę, su ja tiesiogiai siejamą hospitalinès infekcijos riziką bei gydymo kaštus.

\section{Praktinès rekomendacijos}

Dažniausiai pirmojo tipo CD reikalauja padidinto budrumo dẻl jo dekompensacijos (diabetinès ketoacidozès!). DKA gydymo trukmę ITS didinanti hipokalemija, hipoglikemija, gydymas natrio bikarbonato tirpalais ir pernelyg ankstyvas insulino vartojimo nutraukimas yra ir turètų būti išvengti. Gydant DKA, hipoglikemijos atveju ar jos prevencijai reikètų mažinti insulino dozę, o ne visiškai sustabdyti jo vartojimą, nes kito būdo kontroliuoti DKA nèra būtent dèl insulino deficito, o hipoglikemijos korekcijai ir prevencijai padidinti i/v gliukozès tirpalų. Kalemijos realiam ịvertinimui būtinai naudoti sąsają su kraujo $\mathrm{pH}$ ir anksti skirti kalio papildymą. Nevartoti natrio bikarbonato DKA gydymui, nes ši acidozè kyla tik dèl insulino deficito. Galima išvengti pernelyg ilgos DKA gydymo ITS trukmès, gydymo eigoje išvengiant hipoglikemijos, hipokalemijos, insulino pernelyg ankstyvo nutraukimo ir nepagristo natrio bikarbonato skyrimo.

\section{Išvados}

1. Dažniausiai diabetinę ketoacidozę sukèlè 1 tipo cukrinis diabetas. Iki tol nediagnozuotas cukrinis diabetas pasireiškè ketoacidoze dešimtadaliui tirtujų.

2. Lètinis piktnaudžiavimas alkoholiu, ūminè infekcija bei insulino dozavimo pažeidimas dažniausiai predisponavo diabetinę ketoacidozę.

3. Gydant diabetinę ketoacidozę, daugiau kaip pusei pacientų diagnozuota hipokalemija: trečdaliui nustatyta pirminè hipokalemija, kitiems - realiatyvi normo- ar hiperkalemija, kuomet neskyrus kalio papildymo ketvirtadaliui pacientu išsivystė antrinè hipokalemija.

4. Insulino terapijos metu hipoglikemija išsivystè penktadaliui pacientų. Trečdaliui pacientų insulino skyrimas intensyvinant gliukozès tirpalų vartojimą, dèl hipoglikemijos ir normoglikemijos nutrauktas klaidingai, nes išlieka ketonurija.

5. Natrio bikarbonato tirpalų vartojimas didino bikarbonatinio buferio koncentraciją, tačiau ketoacidozei ir ketonurijai įtakos neturejo.

6. Diabetinès ketoacidozès gydymo intensyviosios terapijos skyriuje trukmę dvigubai ilgino infekcinès komplikacijos, hipokalemija, hipoglikemija, nepagristas natrio bikarbonato skyrimas bei insulino nutraukimas dèl hipo- ar normoglikemijos, kol išlieka ketonurija.

\section{Literatūra}

1. Kamel S, Schreiber M, Carlotti A, Halperin ML. Aproach to the treatment of diabetic ketoacidosis. American Journal of Kidney Diseases 2016;68(6):967-72.

https://doi.org/10.1053/j.ajkd.2016.05.034

2. Lee MH, Calder GL, Santamaria JD, MacIsaac RJ. Diabetic ketoacidosis in adult patients: an audit of factors influencing time to normolisation of metabolic parameters. Internal Medicine 2018;48:529-34.

https://doi.org/10.1111/imj.13735

3. Gosmanov AR, Gomanova EO, Dillard-Cannon E. Management of adult diabetic ketoacidosis. Diabetes, Metabolic Syndrome and Obesity: Targets and Therapy 2014;7:255-64.

https://doi.org/10.2147/DMSO.S50516

4. Patel MP, Ahmed A, Gunapalan T, Hesselbacher S. Use of sodium bicarbonate and blood gas monitoring in diabetic ketoacidosis: a review. World Journal of Diabetes 2018;9(11):199-205.

https://doi.org/10.4239/wjd.v9.i11.199

5. Kamel S, Halperin L. Acid-base problems in diabetic ketoacidosis. The New England Journal of Medicine 2015;372 (6):546-54.

https://doi.org/10.1056/NEJMra1207788

6. Westerberg DP. Diabetic ketoacidosis: evaluation and treatment. American Family Physician 2013;87(5):337-46. 
7. Kakusa M, Kamanga B, Ngalamika O, Nyirenda S. Comatose and noncomatose adultdiabetic ketoacidosis patients at the University Teaching Hospital, Zambia: clinical profiles, risk factors, and mortality outcomes. Indian Journal of Endocrinology and Metabolism 2016;20(2):199-205.

https://doi.org/10.4103/2230-8210.176358

8. Azevedo, LCP, Choi H, Simmonds K, Davidow J, Bagshaw SM. Incidence and long-term outcomes of critically ill adult patients with moderate-to-severe diabetic ketoacidosis: retrospective matched cohort study. Journal of Critical care 2017;29(6):971-4.

https://doi.org/10.1016/j.jcrc.2014.07.034

9. Balmier A, Dib F, Serret-Larmande A, De Montmollin E, Pouyet V, Sztrymf B, Megarbane B, Thiagarajah A, Dreyfuss D, Ricard JD, Roux D. Initial management of diabetic ketoacidosis and prognosis according to diabetes type: a French multicentre observational retrospective study. Annals of Intensive Care 2019;91(9):1-8.

https://doi.org/10.1186/s13613-019-0567-y

10. Galm BP, Bagshaw SM, Senior PA. Acute management of diabetic ketoacidosis in adults at 3 teaching hospitals in Canada: a multicentre, retrospective cohort study. Canadian Journal of Diabetes 2019;43 (5):309-15.

https://doi.org/10.1016/j.jcjd.2018.11.003

11. Thewjitcharoen Y, Plianpan P, Chotjirat A, Nakasatien S, Chotwanvirat P, Wanothayaroj E, Krittiyawong S, Himathongkam T. Clinical characteristics and outcomes of care in adult patients with diabetic ketoacidosis: a retrospective study from a tertiary diabetes center in Thailand. Journal of Clinical and Translational Endocrinology 2019;16:1-5.

https://doi.org/10.1016/j.jcte.2019.100188

12. Qari F. Clinical characteristics of patients with diabetic ketoacidosis at the Intensive Care Unit of a University Hospital. Pakistan Journal of Medical Sciences 2015;31(6):1463-66. https://doi.org/10.12669/pjms.316.7550

13. Azoulay E, Chevret S, Didier J, Barboteu M, Bornstain C, Darmon M, Le Gall JR, Vexiau P, Schlemmer B. Infection as a trigger of diabetic ketoacidosis in intensive care-unit patients. Clinical Infection Diseases 2001;32(1):30-5.

https://doi.org/10.1086/317554

14. Randall L, Begovic J, Hudson M, Smiley D, Peng L, Pitre N, Umpierrez D, Umpierrez G. Recurrent diabetic ketoacidosis in inner-city minority patients: behavioral, socioeconomic, and psychosocial factors. Diabetes Care 2011;34(9):1891-6. https://doi.org/10.2337/dc11-0701

15. Crasto W, Htike ZZ, Turner L, Higgins K. Management of diabetic ketoacidosis following implementation of the JBDS guidelines: where are we and where should we go? British Journal of Diabetes and Vascular Disease 2015;15 (1):11-16. https://doi.org/10.15277/bjdvd.2014.040

16. Dhatariya KK, Nunney I, Higgins K, Sampson MJ, Iceton
G. National survey of the management of diabetic ketoacidosis (DKA) in the UK in 2014. Diabetic Medicine 2016;33 (2):252-60.

https://doi.org/10.1111/dme.12875

17. Pasquel FJ, Tsegka K, Wang H, Cardona S, Galindo RJ, Fayfman M, Davis G, Vellanki P, Migdal A, Gujral U, Narayan KMV, Umpierrez GE. Clinical outcomes in patients with isolated or combined diabetic ketoacidosis and hyperosmolar hyperglycemic state: a retrospective, hospital-based cohort study. Diabetes Care 2019;43(2):349-57.

https://doi.org/10.2337/dc19-1168

18. Uribarri J, Oh MS, Carrol HJ. Hyperkalemia in diabetes mellitus. Diabetes Complications 1990;4(1):3-7.

https://doi.org/10.1016/0891-6632(90)90057-C

19. Nirantharakumar K, Marshall T, Kennedy A, Narendran P. Hypoglycaemia is associated with increased length of stay and mortality in people with diabetes who are hospitalized. Diabetic Medicine 2012;29(12):445-8.

https://doi.org/10.1111/dme.12002

20. Krinsley J, Schultz MJ, Spronk PE, van Braam Houckgeest F, van der Sluijs JP, Mélot C, Preiser JC. Mild hypoglycemia is strongly associated with increased intensive care unit length of stay. Annals of Intensive Care 2011;49(1):1-9.

https://doi.org/10.1186/2110-5820-1-49

21. Krinsley JS, Schultz MJ, Spronk PE, Harmsen RE, van Braam Houckgeest F, van der Sluijs JP, Mélot C, Preiser JC. Mild hypoglycemia is independently associated with increased mortality in the critically ill. Critical Care 2011;15(4):1-10.

https://doi.org/10.1186/cc10322

22. Viallon A, Zeni F, Lafond P, Venet C, Tardy B, Page Y, Bertrand JC. Does bicarbonate therapy improve the management of severe diabetic ketoacidosis? Critical Care Medicine 1999;27(12):2690-3. https://doi.org/10.1097/00003246-199912000-00014

23. Latif KA, Freire AX, Kitabchi AE, Umpierrez GE, Qureshi $\mathrm{N}$. The use of alkali therapy in severe diabetic ketoacidosis. Diabetes Care 2002;25(11):2113-4.

https://doi.org/10.2337/diacare.25.11.2113

24. Guneysel O, Guralp I, Onur O. Bicarbonate therapy in diabetic ketoacidosis. Bratislavske Lekarske Listy 2008;109(10):453-4.

25. Duhon B, Attridge RL, Franco-Martinez AC, Maxwell PR, Hughes DW. Intravenous sodium bicarbonate therapy in severely acidotic diabetic ketoacidosis. Annals of Pharmacotherapy 2013;47(7-8):970-5. https://doi.org/10.1345/aph.1S014

26. Green SM, Rothrock SG, Ho JD, Gallant RD, Borger R, Thomas TL, Zimmerman GJ. Failure of adjunctive bicarbonate to improve outcome in severe pediatric diabetic ketoacidosis. Annals of Emergency Medicine 1998;31(1):41-8.

https://doi.org/10.1016/S0196-0644(98)70279-3 


\section{ASPECTS OF TREATMENTS AND OUTCOMES OF} DIABETIC KETOACIDOSIS

D. Adukauskienė, L. Jokūbonienė, E. Kazėnaitė, E. Mašanauskienė, A. Gečionienė

Keywords: diabetic ketoacidosis, diabetes mellitus, hypokalemia, hypoglycaemia, sodium bicarbonate.

Summary

Objective: Aim of study was to assess the origin of diabetic ketoacidosis (DKA), estimate the rate of DKA treatment complications, etiology, relate them with length of stay (LOS) in intensive care ICU and on the basis of the study data give opportunities for doctors to optimize of DKA treatment tactics and options.

Methods: Analysis of retrospective cohort study data of 120 patients (pt) treated for DKA at ICU at 6 yr period has been carried out. DKA treatment complications, use of sodium bicarbonate for ketoacidosis and their association with LOS in ICU were analysed. SPSS 23.0 was used for statistic calculations. Traits evaluated as significant at $\mathrm{p}<0.05$.

Results: DKA was caused by alcohol abuse in $29 \%$, infection $-28 \%$, incorrect insulin dosage $-28 \%$, severe comorbidity $-5 \%$ and unidentified causes in $10 \%$ of pt. During DKA treatment hypokalemia was recorded in $53 \%$, LOS in ICU was $52.9 \pm 29.7$ vs $32.8 \pm 18.6 \mathrm{~h}, \mathrm{p}<0.05$. Insulin use has caused hypoglycaemia in
$18 \%$, LOS in ICU $63.2 \pm 38.5$ vs $38.9 \pm 21.2 \mathrm{~h}, \mathrm{p}<0.05$. Insulin use was interrupted in case of normo - and hypoglycaemia with still persisting ketoacidosis in $33 \%$, LOS in ICU was $56.5 \pm 30.7$ vs $37.0 \pm 22.5 \mathrm{~h}, \mathrm{p}<0.05$. Sodium bicarbonate has been given for symptomatic treatment of ketoacidosis during first day of DKA in $28 \%$ with stable hemodynamic, $55.2 \pm 27.5$ vs $39.1 \pm 25.6 \mathrm{~h}, \mathrm{p}<$ 0.05 . Total duration of treatment in the ICU was $9-163 \mathrm{~h}(45.1$ $\pm 34.2 \mathrm{~h})$ : due to infection was $19-163 \mathrm{~h}(61.7 \pm 41 \mathrm{~h})$, non-infection causes $9-97 \mathrm{~h}(31.6 \pm 19.4 \mathrm{~h}), \mathrm{p}<0.05$.

Conclusions: Diabetic ketoacidosis was predisposed mostly by alcohol abuse, infection and incorrect insulin dosage. Hypokalemia, hypoglycemia, precocious interruption of insulin use were recorded as complications of diabetic ketoacidosis treatment which have prolonged length of stay in Intensive Care Unit as well as a symptomatic treatment of ketoacidosis with sodium bicarbonate. The length of stay in ICU it was found to be twice longer also in case of infection as a cause of diabetic ketoacidosis.

Correspondence to: laurajzkt@gmail.com

Gauta 2021-04-01 